\title{
CONTRACTUAL TERMS IN MUSHARAKAH AND MUDARABAH RESTRICTING THE PROFIT SHARE OF A PARTNER OR FACILITATING LATER AMENDMENTS TO THE AGREED RATIO: A SCRUTINY
}

\author{
Muhammad Abdurrahman Sadique*
}

\begin{abstract}
Equity participation in joint ventures as envisaged in Shari'ah consists of a business relationship based on mutual sharing of gains and liability. Such partnerships as prevalent in every sphere of commerce generally involve the possibility of unlimited gains for each partner in theory, without limitations attached to the amount of return to any single partner. A central pillar of the equity structure in Shari'ah is the unbridled operation of the profit sharing ratio. Restriction of its application to a stipulated level of profits, thereby enabling a partner to claim unlimited profits while the profit share of the other is restricted to a maximum ceiling cannot be regarded to be consistent with the theory of equity participation. While such measures could realise some temporary benefit to Islamic banks, with continued practice, they could become deep-rooted in the concept of equity
\end{abstract}

Assistant Professor, Ahmad Ibrahim Kulliyyah of Laws, International Islamic University Malaysia. E-mail: sadique@iium.edu.my. 
financing itself, thus making it operate subservient to debt financing norms. Islamic banks should attempt to alienate their identity from being lending institutions, a pioneer step towards which would be to implement a dynamic profit and loss sharing mechanism.

Keywords: Musharakah, Mudarabah, contractual terms, profit sharing, ratio, restriction, amendment.

\title{
TERMA KONTRAK DALAM MUSYARAKAH DAN MUDARABAH YANG MENYEKAT BAHAGIAN KEUNTUNGAN SEORANG RAKAN KONGSI ATAU YANG MEMUDAHKAN PINDAAN KEMUDIAN HARI PADA NISBAH YANG DIPERSETUJUI: SATU PENELITIAN
}

\begin{abstract}
ABSTRAK
Penyertaan ekuiti dalam projek bersama seperti yang dibayangkan dalam Syariah terdiri daripada hubungan bisness yang berasaskan perkongsian bersama perolehan dan liabiliti. Perkongsian sebegini yang lazim dalam setiap sfera perdagangan secara umumnya membabitkan kemungkinan perolehan tak terhad bagi setiap rakan kongsi pada teorinya, tanpa pengehadan jumlah pulangan kepada mana-mana rakan kongsi. Tiang seri struktur ekuiti dalam Syariah ialah operasi nisbah perkongsian keuntungan yang tidak dikekang. Mengehadkan pemakaian nisbah perkongsian keuntungan kepada tahap keuntungan yang ditetapkan, dan dengan itu membolehkan seseorang rakan kongsi untuk menuntut keuntungan tanpa had sedangkan bahagian keuntungan rakan kongsi yang lain dihadkan kepada satu had maksimum, tidak
\end{abstract}


boleh diambil kira sebagai selaras dengan teori penyertaan ekuiti. Walaupun langkah sebegini boleh membawa sedikit manfaat sementara kepada bank Islam, dengan amalan berterusan, langkah ini boleh menjadi berakar umbi dalam konsep pembiayaan ekuiti, dan dengan demikian menjadikannya beroperasi menuruti norma-norma pembiayaan hutang. Bank Islam perlu cuba menyisihkan identiti institusi pemberi pinjaman, satu langkah pertama ke arah melaksanakan satu mekanisme perkongsian keuntungan dan kerugian yang dinamik.

Kata kunci: Musyarakah, Mudarabah, terma kontrak, perkongsian keuntungan, nisbah, pengehadan, pindaan

\section{INTRODUCTION}

In ventures financed on equity basis by Islamic financial institutions, in order to achieve Shari'ah compliance, it is ensured in general that the profit sharing ratio is fixed at the inception of the contract. Despite this, certain measures are sometimes adopted that result in altering the mechanism of profit sharing before the finalisation of the venture. These include the option to alter the profit sharing ratio after the inception of the contract. The Shari'ah perspective of similar measures are analysed hereunder.

It is well known that in equity based financing in Shari'ah, knowledge of the ratio of profit and loss distribution forms a core requirement. In equity based facilities offered by Islamic financial institutions, this principle is generally adhered to, and the ratio of profit sharing agreed between the bank and the client is stipulated in the contractual agreement. Although the method adopted for arriving at this ratio needs further discussion, it is generally conceded that the basis for profit distribution should be agreed as a ratio of the total profit, and not as a lump sum allocated to a partner or as a percentage of the capital. As such, the mushârakah / mudârabah ventures embarked on by Islamic banks define the profit shares accruing to the partners as a ratio of the total profit realisable through the venture. 
In equity investments made by the bank in joint ventures with clients, the contractual agreement refers to the ratio of profit division between the bank and the joint partner. The usual process in practice for determining this ratio involves calculation for achieving a predetermined return on the capital exposure undertaken by the bank with primary focus on the planned duration of the venture. The capital return calculated thus is converted into a percentage of the expected profit, and the basis of profit allocation is reflected as a ratio on the agreement, for the purpose of ensuring Shari'ah compliance. ${ }^{1}$ As regards distribution of loss, agreements for investment in joint investment accounts ${ }^{2}$ as well as secondary investment by the bank with clients are observed to lay down clearly that loss would be shared in proportion to the capital investment of the parties, as required by the Shari'ah.

However, despite of the clear formulae on profit and loss sharing agreed by the parties in such equity ventures, Islamic banks feel constrained at times to incorporate clauses that override them, and permit the final distribution of profits to be on a footing other than what was agreed initially. This could be achieved through means such as reserving the right to alter the profit sharing ratio after the inception of the contract, or by declaring that profits earned over and above a defined ceiling would accrue to one of the contractors unilaterally or that the other partner would relinquish such profits. Alternatively, the partners may agree on different profit sharing ratios for different stratums of profit earned through the venture. These provisions provide a level of flexibility in the division of profits, and may be used for achieving a variety of purposes. They may help regulate the profit accruing to investment account holders, while enabling the bank, when losses are not involved, to achieve a

1 The appropriateness of this procedure, together with possible alternatives, has been discussed in the author's paper "Profit and Loss Allocation among Islamic Bank and Client Partner in Equity Financing: Practice, Precepts and Alternatives," Journal of King Abdul Aziz University on Islamic Economics., Vol. 22 No. 1 (2009), pp: 29-52.

2 Loss distribution in the case of joint investment accounts remain a tricky issue, as the investment and profit distribution mechanisms adopted in these accounts almost preclude the possibility of loss distribution in an equitable manner. A detailed analysis of this is done in the author's forthcoming work on investment accounts of Islamic banks. 
minimum level of return on its investments. They can be resorted to for restricting the bank's income to the due return on capital as dictated by the rate applied, while abandoning any additional profit gained above such return to the client. The latter measure aims at inducing clients to avail of Islamic banking facilities instead of resorting to interest based loans offered by conventional banks, by preventing the profit share of the bank from exceeding the interest charged by conventional banks for similar facilities. Despite of the reasons that necessitate the employment of such provisions, the level of their Shari'ah admissibility could vary according to the nature of the particular provision. Two such provisions, namely, for unilateral entitlement to profits exceeding a stated amount and for revising the profit sharing ratio after completion of operations, are discussed below. Before taking up these provisions, some aspects of crucial relevance are analysed.

\section{IMPORTANCE OF AGREEMENT ON PROFIT AND LOSS SHARING RATIOS}

It would be significant here to verify the level of importance given by Shari'ah to stipulating the profit and loss sharing ratios in equity based contracts. In joint ventures on shirkah and mudârabah, the knowledge of profit and loss sharing ratios is imperative at the inception of the contract. $^{3}$ Although there appears to be some difference on whether it is necessary to stipulate these aspects in the agreement, a perusal of accepted works of the schools would reveal that where this is not required, it is due to the fact that certain schools do not recognise the possibility of any variation occurring pertaining to these. Thus, the Shâfici school holds that profit (as well as loss) in shirkah would necessarily be owned by the partners in proportion to their respective capitals, irrespective of whether this fact is stipulated in the agreement or not. If any condition is agreed to the contrary, the contract becomes invalid. The position of the

\footnotetext{
3 Al-Kâsâni, Badâ ' $i^{c}$ al-Sanâ ' 'ic , Vol. 6, 94, 135. See for details author's Essentials of Mushârakah and Mudârabah (Kuala Lumpur, IIUM Press, 2009), sections on ratio of profit and loss in shirkah, and in mudârabah, sections on declaring the proportion of profit and profit share being fixed as a ratio of the total profit.
} 
Mâliki school in this respect is similar, who also state that labour, too, is to be contributed by the parties in proportion to their capital investment, even when these aspects are not stipulated in the contract. ${ }^{4}$ Hanbali jurists, who do not consider it necessary that profits be divided on the basis of capital contribution, hold that when partners in a contract of shirkah do not stipulate the ratio of profit distribution, it will be divided according to the capital investment ratio. ${ }^{5}$ With regard to mudârabah, all schools hold it necessary that the proportion of each partner's profit should be known at the inception of the contract, so much so that ignorance of this aspect results in the invalidity of the contract. Where general reference is made in the contract to profits being shared by the parties without specifying the exact proportion of each contractor, all schools of Islamic law regard the contract valid, as reference to sharing is taken to denote equal entitlement to profits among the partners. Therefore, profits are divided equally between the financier and the fund manager in this instance. ${ }^{6}$

It is clear from the above that all schools of Islamic law consider it necessary that the profit sharing ratio be clearly fixed at the outset of the equity relationship. The emphasis placed on this issue is justified in view of the fact that sharing of profit (and loss) happens to lie at the foundation of equity relationships. Therefore, it is imperative that the means of laying claim to a proportionate share thus be clearly agreed on at the inception of the relationship. This is to ensure the complete consent of the partners to adopt the equity platform, where they forgo the right to claim wages, which they would have been entitled to had they adopted an ijârah platform. ${ }^{7}$ As such, any uncertainty in this regard is held to violate the objective of choosing the equity platform, and thus would

$4 \quad$ Al-Nawawi, Rawḍh al-Ṭ̂alibîn, Vol. 3, 516, al-Khurashi, Hâshiyah alKhurashi, Vol. 6, 349.

5 Ibn Qudâmah, al-Mughni, Vol. 5, 140, 147.

6 Ibn Qudâmah, al-Mughnî, Vol. 5, 142, al-Nawawi, Rawḍh al-Tâlibîn, Vol. 4, 203, al-Kâsânî, Badâ' 'ic al-Sanâ'ic, Vol. 6, 135, al-Khurashi, Hâshiyah al-Khurashi, Vol. 7, 151.

7 In place of the fixed and defined wages necessarily required under an ijârah platform for labour, the maximum measure of safety that could be provided for labour rendered under a mudârabah / mushârakah arrangement would be a clear and unambiguous stipulation regarding the ratios of profit and loss sharing. 
result in the invalidity of the partnership. The Hanafi jurists have gone so far as to consider profits to be the subject matter in the contracts of both shirkah and mudârabah, ignorance of which would lead to their invalidity. ${ }^{8}$

\section{PROFIT SHARE BEING FIXED AS A PROPORTION}

After verifying the necessity of determining the profit and loss sharing ratios in equity relationships, we may proceed to examine the nature of the profit allocation upheld by the Shari'ah. Jurists in general insist that the profit allocation between the partners take place as undivided and indistinguishably merged portions $\left(j u z\right.$ 'shâ' $\left.i^{c}\right)$, i.e. as a proportion of the total profit. Allocation of a specific lump sum amount to either partner invalidates the contract. As far as the Shâfici and Mâliki schools are concerned, this is in accordance with their strict adherence to the capital investment ratio as the sole basis for profit allocation in shirkah. In the case of mudârabah, Shâfici jurists have clearly upheld that profit should be shared among the parties based on a known proportion (juz'iyyah); allotment of a lump sum such as ten to either party, even in addition to a proportionate share, would invalidate the contract. ${ }^{9}$ The position of Mâliki jurists is similar. Al-Mudawwanah categorically rules out the possibility of assigning a specific sum, however small it is, to one of the partners in mudârabah, and terms it prohibited (harâm). It stresses that the profit should be shared in proportion, every unit of it being subject to sharing, ${ }^{10}$ and observes that this is the nature of qirâd (i.e. mud̂ârabah) of Muslims. The profit share being agreed as an undivided proportion and not as a specified amount is a necessary condition for the validity of mudârabah. ${ }^{11}$

\footnotetext{
8 Al-Kâsânî, Badâ' 'ic al-Sanâ' 'ic, Vol. 6, 94, 135.

9 Al-Nawawi, Raw ̣̦ah al-Ṭâlibîn, Vol. 4, 204, al-Sharbîni, Mughni alMuḥtâj, Vol. 2, 422, 423, al-Mâwardi, al-Hâwi al-Kabîr, Vol. 7, 312. Abd al-Salām Saḥnūn ibn Sa`īd, al-Mudawwanah al-Kubrāa, Vol. 12, 89, 91 .

11 Muhammad ibn Abd al-Raḥmân al-Maghribi al-Hattâb, Mawâhib alJalîl, Bayrût, Dâr al-Fikr, 1398H, Vol. 5, 358, Muḥammad ibn Aḥmad ibn Juzayy al-Kalbi al-Gharnâti, al-Qawânîn al-Fiqhîyyah, (publisher unknown), Vol. 1, 186.
} 
The Mâliki jurist al- ${ }^{\mathrm{C}}$ Adawi, among others, has succinctly expressed the approved nature of the profit share as 'a share of unknown quantity and known proportion' such as a quarter of the total profit, and stresses that it should be fixed as a proportion of the total profit solely. ${ }^{12}$

It would be pertinent to scrutinize the nature of profit allocation in the Hanafi and Hanbali schools, who do not insist on adopting the capital investment ratio for this purpose. These two schools are seen to emphasise that the profit shares of equity partners should be mutually agreed on as undivided and indistinguishable portions (mushâ $)^{13}$ that are clearly known. ${ }^{14}$ Hanafi jurists consider the non-existence of any element leading to disruption of sharing (qat al-shirkah) a precondition for the validity of shirkah, and hold the legal consequence $(\mathrm{hukm})$ of shirkah to be sharing of profits. Assigning a lump sum of the profits to either partner results in the invalidity of shirkah, as it violates this precondition. ${ }^{15}$ In support of the requirement that the profit share of the mudârib and that of either partner in shirkah should necessarily be fixed as an undivided and indistinguishable portion (juz'mushâc), the Hanbali jurist Ibn Qudâmah al-Maqdisi in his al-Kâfí, among others, has cited the narration that the Holy Prophet (Sal.) had contracted $m u^{c} \hat{a}$ malah with the occupants of Khaybar against a proportionate share (shatr) of its produce. He observes that mudârabah is similar to mucamalah in this respect. ${ }^{16}$ Al-Nawawi has explained shatr to be a known portion such

12

Ali al-Sa'̄idi al-'Adawi, Hāshiyah al-'Adawi, Bayrūt, Dār alFikr, 1412H, Vol. 2, 268, Ahmad ibn Ghunaym al-Nafrāwi al-Māliki, al-Fawākih alDawāni, Bayrūt, Dār al-Fikr, 1415H, Vol. 2, 123.

13 This is essentially similar in meaning to the term used by other jurists (juz'sha' $i^{c}$ ).

'Alî ibn Sulaymân al-Mardâwi, al-Inșâf, Vol. 5, 412, Muwaffaq al-Dîn 'Abdullah ibn Aḥmad Ibn Qudâmah al-Maqdisi, al-Kâfi fî Fiqh ibn Hanbal, Bayrût, al-Maktab al-Islâmi, 1988, Vol. 2, 267, and al-Mughnî, Vol. 5, 140, al-Kâsânî, Badâ' 'ic al-Sanâ' 'i', Vol. 6, 94, 135.

15 Al-Hașkafi, al-Durr al-Mukhtar, printed with Ibn ${ }^{\mathrm{c}}$ Abidîn, Radd alMuhtâr, Vol. 4, 305, 316.

16 Ibn Qudâmah, al-Kâfi fỉ Fiqh ibn Hanbal, Vol. 2, 267, al-'Imrâni, alBayân, Vol. 7, 190. The hadith, reported by ibn Umar (Rad.), is recorded by Muslim (Vol. 3, 1186, hadîth No. 1551) and Abû Dâwûd (Vol. 3, 262, hadith No. 3408) among others. 
as a half or a quarter. ${ }^{17}$ The Hanbali legal manual al-Mughni narrates the consensus of scholars in this issue as recorded by Ibn al-Mundhir. ${ }^{18}$ Therefore, apportioning a specific amount of the profit, such as ten or hundred, to either partner is not allowed. The reason for this prohibition is that the contract of shirkah dictates sharing of profit, and the entitlement of a partner to a specific amount would thwart such sharing. This ruling is applicable even in the case of mudârabah, as the latter could be regarded as a type of shirkah in that it entails partnership in profit. ${ }^{19}$

The above bears out that allocation of a specific sum to a partner is disapproved because it contradicts the principle of common sharing in the proceeds. The texts on this issue indicate that according to jurists, sharing is considered necessary to occur in the whole of the profit. This suggests that the total profit realised through the venture should be allocated to the partners on the basis of joint sharing, where the possibility of a partner laying claim to a specific portion of the profit exempted from joint sharing is wholly negated. It appears that the shirkah or joint ownership of the partners in the profits realised, which takes place in both shirkah as well as mud̂arabah according to al-Kâsâni, could be compared to shirkah al-milk, where each portion of the relevant entity is jointly owned. Common ownership would cease only at the point of liquidation and division, when the partners would agree on the physical division of the profits among them, thus restricting the entitlement of each to an identified portion of the profit and abandoning his joint

$M u^{c} \hat{a}$ malah, also referred to as musâqâh, is a contract between an owner of date palms or grapevines and a farmer for the upkeep of the plantation against a share in the produce, a contract recognised as valid by the majority of jurists except Imâm Abû Hanîfah. Al-Nawawi too has alluded to the similarity borne by both $m u^{c} \hat{a} m a l a h$ and muzârac $a h$ (a contract between a landowner and a farmer for plantation against a share in the produce) to mudârabah, the latter being upheld by ijmâ. See al-Nawawi, Sharḥ al-Nawawi calâ Sahịh Muslim, Bayrût, Dâr Ihyâ al-Turâth al-c'Arabi, 1392H, Vol. 10, 210.

18 Ibn Qudâmah, al-Mughnî, Vol. 5, 140.

19 Al-Kâsânî, Badâ' 'ic al-Sanâ' 'ic Vol. 6, 94. Mâliki jurists too have considered a variety of shirkah to exist with regard to mudârabah profits prior to their division. See al-Dardîr, al-Sharh al-Kabîr, Vol. 3, 517. 
ownership in the rest, in a manner that could be compared with sulh. ${ }^{20}$ It could be observed that the concept of joint sharing in an entity cannot be reconciled with an instance where one partner is held to own a specific and defined amount, as the latter negates the possibility of jointly sharing in each component of the entity.

Through disrupting the mechanism of sharing the profit, such a condition could lead to injustice to either party in different situations. In the event the total profit accruing to the venture only amounting to the lump sum, the whole of it would be claimed by one of the contractors. If the profit realised is even less, the stipulation would lead to part of the capital being given to the partner entitled to the lump sum. On the other hand, if the venture results in huge profits exceeding the levels anticipated, the party entitled to the fixed sum would be prevented from claiming any portion of the excess. ${ }^{21}$

\section{ENTITLEMENT OF A PARTNER TO A FIXED AMOUNT TOGETHER WITH HIS SHARE}

Due to the above reason, Hanafi and Hanbali jurists have not recognised the possibility of allocating a specific amount of profit to one of the partners even in the form of an addition to the basic profit share agreed on as a ratio. Thus, where the partners agree that one of them is entitled to a third, i.e. $33 \%$, of the total profit and an additional hundred, the latter being a specific sum stipulated in addition to the agreed proportionate share, the contract is held invalid. Ibn Qudâmah has narrated in this context the consensus recorded by Ibn al-Mundhir that the contract of mudârabah becomes void through the stipulation of a specific amount to either partner or both of them, and has asserted that this is the verdict of Imâms Mâlik, al-Awzâci al-Shâfici Abû Thawr and the Hanafi jurists. ${ }^{22}$

$20 \quad$ The comparison with shirkah al-milk here, as obvious, is not complete, as profits do not have an entity of their own until liquidation and separation, and remain mingled with the capital during the tenure of the contract. For the nature of common ownership under shirkah almilk, see author's Essentials of Mushârakah and Muḍ̂rabah: Islamic texts on Theory of Partnership, Kuala Lumpur, IIUM Press, 2009.

21 Ibn Qudâmah, al-Mughni, Vol. 5, 148.

22 For details see ibn Qudâmah, al-Mughnî, Vol. 5, 148. 
Similarly, agreement on a specific sum being deducted from the proportionate share of profit of a partner would result in the invalidity of the contract. Hanafi jurists argue that such a condition would interfere with a genuine sharing of the profit, ${ }^{23}$ which could violate the objective of partnership. This further supports the above inference that jurists had envisaged sharing in the whole profit on the basis of an agreed ratio. Hence, sharing in the profits could not be held to materialise if a lump sum is reserved for one party even when a ratio is applied for division of the remaining profit, as the lump sum reserved thus would be exempt from common sharing. Hanafi jurists have explored various instances regarding the incorporation of such clauses in muḍ̂abah. ${ }^{24}$

\section{EXCLUSIVE RIGHT OF A PARTNER TO PROFITS IN EXCESS OF A DEFINED AMOUNT}

It was established above that Shari'ah requires precise knowledge of the profit sharing ratio at the inception of a mushârakah / mudârabah relationship, even according to the schools that regard the partners entitled to playing a role in its determination, and that exemption of even a part of the profit from such proportionate division would invalidate the contract. We could now consider the stipulation that where profits are realised in excess of a defined ceiling, the excess profit would be claimed by one of the partners to the exclusion of the other.

Such stipulation in mushârakah / mudârabah agreements is sought for the purpose of allowing a partner who plans only to realise a certain amount of profit through the venture and is willing to forgo any excess in favour of the other party. The stipulation would be effective only where profits in excess of the defined ceiling are realised. If the case is otherwise, profits realised would be shared according to the specific ratio agreed by the partners as is usual in equity ventures, and the stipulation would remain inoperative. Similarly, if the joint venture results in loss, the loss would be borne by the partners proportionate to their capital investment, unhampered by the additional stipulation.

\footnotetext{
23 شرط يوجب قطع الثركة في الربح $\quad$ i.e., a recurrent expression appearing in this context. See alKāsānī, Badā' 'i’ al-Sanā' 'ie, Vol. 6, 135.

24 Al-Kâsânî, Badâ' 'ic al-Ṣanâ' 'ic, Vol. 6, 136.
} 
This condition could be resorted to by Islamic banks in investment accounts offered to the public usually on mudârabah basis, and also in equity ventures jointly initiated with a client as the mudârabah / mushârakah working partner. The purpose in both instances is to limit the amount of profit the bank achieves through the venture to a certain predetermined margin, generally reflected as a percentage of return on the capital invested. The excess profit renounced thus by the bank in favour of the joint partners could be defined as what exceeds a specific percentage of the total capital before division of profits, or as what is realised by the bank as its profit share in excess of a specific percentage of its capital contribution. It was mentioned above that alluding to a percentage of a known capital is materially equivalent to referring to a fixed sum. Thus, in both instances the application of the profit sharing ratio is confined to a specific sum, any profit realised in excess of it being entitled to by the equity partner solely, to the exclusion of the bank. While any amount of profit realised through the venture below the specified sum or equal to it is subjected to division among the partners according to the agreed ratio, any excess would be exempted from such division, irrespective of the amount.

The ultimate consequence of this stipulation is that the bank is enabled to claim a specific sum as the return on its investment, however, only when the venture has succeeded in realising a minimum level of profit. Even if the venture generates profits over and above the minimum level thus identified, the bank would suffice itself with claiming the fixed amount of return, irrespective of the size of the total profit. However, if the venture realises less profits than anticipated due to acceptable reasons and falls short of achieving the minimum level, the bank is bound to share in the realised profits according to the agreed ratio, or even suffer capital loss in an extreme situation.

Would such an agreement be at variance with the requirement that profits should be jointly entitled to by the partners, and refute the possibility of sharing in profits (shirkah fi al-ribh) deemed necessary by jurists both in shirkah as well as mudârabah? Allotment of a specific sum to a partner, either in isolation or coupled with a proportionate share of profits, was disapproved by jurists as it was held to negate the principle of sharing the profit, i.e. the whole of it. Sharing, as described above, requires that the share accruing to a partner be fixed as an undivided share of the whole profit, i.e. a proportion, both in mushârakah as well as mudârabah, so that the share of each partner may fluctuate freely 
corresponding to the profit realised through the venture, irrespective of its volume. In ruling out the application of the ratio to profits earned in excess of a specific sum, there appears to be an inconsistency with this fundamental characteristic of profit division prescribed for equity relationships. However, the situation here cannot be fully equated with that of allocating a specific sum to a partner, as in the latter case, there is a possibility of the partner who is entitled to the specific sum securing the whole profit, when the entire profit realised through venture does not exceed the specific sum. In the circumstance in question, although the bank is entitled to a specific sum when the venture achieves a minimum level of profits, this could occur only after the client has secured his share of profit as dictated by the agreed ratio within the set minimum level. Hence, the stipulation could not possibly lead to total deprivation of a partner from profits in any situation.

\section{Current practice}

The stipulation in question being one that interests Islamic bankers greatly for reasons that will be presently discussed, several Shari' ah supervisory boards and other bodies related to Islamic banking have taken it up for consideration. One of the first who have confronted this issue appears to be the Shari'ah supervisory board of the Faisal Islamic Bank of Sudan. In a collection of rulings made by this board published in 1982, a question related to the issue is answered. The question probes the possibility of remitting profits that exceed a given sum to the partner while agreeing to share profits equally. ${ }^{25}$ The answer, while upholding the invalidity of

25 Shari'ah Supervisory Board of Faisal Islamic Bank Sudan, Rules of the Shari'ah Supervisory Board English Series No. 5, Faisal Islamic Bank Sudan, 1982, 92, Question No. 11. The relevant part of the question is as follows: ' $\ldots$ Is it permissible for FIB in such situations to make a mutual agreement with the partners to share the realized profits equally, i.e. $50 \%$ each, provided that when the profits exceeds a given sum, e.g. LS 40,000 or more the bank will accept a given sum from that amount, say LS 20,000 in the given example, and remit the remainder to the partner, notwithstanding the surplus in profits realized...?' The question and the answer are also reproduced in A Compendium of Legal 
partnership due to stipulating a fixed sum to one of the parties where this leads to a partner being deprived of sharing the profits, asserts that if the stipulation is not expected to result in such deprivation, it would be lawful. This is supported with a quotation from a book named al-Bahr alZakhkhâr, which reads as follows: "if one of the parties asks for ten if the profits exceed a stated amount, the stipulation is correct and binding as there is no reason to consider it invalid." Accordingly, the answer holds the agreement in this instance permissible, since the profit is shared in common between the two parties; stipulating what exceeds the specified amount of profits for the bank's partner will not result in not sharing in the profits because the partner will not be entitled to it except after both the bank and the partner had taken $50 \%$ of the agreed amount of profits when it is realised.

A similar position has been upheld in verdicts issued by several other bodies subsequently. The second conference of Islamic banks held in Kuwait in 1983 resolves that it is permissible to stipulate a specific sum to any equity partner when the profits exceed a specified limit. This stipulation is not deemed to result in non-sharing of the profit. ${ }^{26}$ The conference on Islamic economics held in al-Madînah in 1983 rules it lawful for the financier to agree with the fund manager that if profits exceed the capital invested, e.g., by $15 \%$ in a year, the excess will accrue to the fund manager, provided the profit is divided based on calculations done in accordance with the agreed proportion. ${ }^{27}$

Following the precedent set by these resolutions, the Shari'a Standards of AAOIFI 2002, while negating the possibility of stipulating a lump sum of profit for a partner, allows the partners in mudârabah or mushârakah to agree that if the profit realised were above a certain

Opinions on the Operations of Islamic Banks (by Yusuf Talal DeLorenzo (ed.), London, Institute of Islamic Banking and Insurance, 2001, 258, hereinafter referred to as the Compendium), however, with some critical flaws that have made the meaning ambiguous.

26 Dubai Islamic Bank, al-Fatâwa al-Sharicîyyah fî̀ al-Acmâl alMasrafiyyah, $2^{\text {nd }}$ Ed., 1996, Vol. 1, 32.

27 Dubai Islamic Bank, al-Fatâwa al-Sharicîyyah fî al-Acmâl alMașrafíyyah, Vol. 1, 32, The Compendium, 214, Research and Development Dept. of Dallah Albaraka, Fatawa: Shariah Rulings on Economics, Jeddah, Dallah Albaraka, 1994, 97. 
ceiling, the excess would belong to a particular partner. ${ }^{28}$ The basis for this ruling, as given, is that this stipulation is not inconsistent with profit sharing. Reference to the work al-Bahr al-Zakhkhar is cited in support.

\section{Analysis}

The position maintained by these bodies appears to have considered the stipulation in question not contrary to sharing in profits (shirkah fi alribh), as the partner securing the fixed lump sum (i.e. the bank, invariably) when the profits reach the agreed ceiling, or the other partner, cannot be held to be deprived of a share in the proceeds in any situation. Since the bank would be entitled to a part of the profits, even though static and unvarying corresponding to the volume of total profits realised, and the other partner, too, would succeed in securing the balance, none of the partners is totally deprived. Consequently, sharing in the profits is considered to have materialised in an acceptable manner. According to this approach, as long as the agreement results in each partner securing some part of the profit, even though not always in accordance with a ratio, it is deemed sufficient for the validity of the contract. This could imply that the prohibition of assigning a lump sum to a partner would be applicable only when it could result in a partner being totally deprived of profits in some situation. Therefore, if such additional measures could be included in the agreement that could prevent its occurrence, specifying a lump sum to a partner should be acceptable, and the requirement of sharing in profits considered fulfilled.

In the light of the preceding discussion pertaining to the nature of the profit share, it is observed that the above inference, although deserving merit on its own, could not be held to be consistent with the perception of sharing in profits as dictated by the theory of equity contracts. As clearly set forth by jurists of all schools of Islamic law, the profit share of each partner in an equity contract is necessarily perceived to be an undivided portion $\left(j u z^{\prime} m u s h \hat{a}^{c}\right)$ of the whole profit. The purpose of this requirement $3 / 1 / 5 / 9$ and mudârabah standard No. $8 / 5$. The same position is reiterated in Sharia Standards 2010, 208 and 237. 
is clear; the profit share should fluctuate freely with the increase or decrease of the total profit generated, so that at any given volume of profits realised, the partners could equitably claim a proportionate share according to the ratio adopted. Thus, the whole profit realised through the venture would be subject to sharing between the partners based on the agreed ratio, which process is construed as shirkah fi al-ribh or sharing of profits, a precondition for the validity of equity contracts. The primary reason a stipulation assigning a lump sum to either partner, either alone or coupled with a proportionate share of profits, is disapproved evidently is that it interferes with the unhindered functioning of the ratio in dividing profits among partners, referred to as qat al-shirkah or disruption of sharing. The possibility of deprivation of a partner from any share in the profits in certain situations is only an adverse outcome of this stipulation, and may not be held to be the fundamental reason for the invalidity of the contract in this event. Thus, the mere absence of this particular outcome would not necessarily mean that sharing in profits as envisaged in equity relationships has materialised. In addition, a negative outcome pointed out by jurists ${ }^{29}$ is clearly existent in the situation in question, namely, that of the partner entitled to the fixed amount upon the profits reaching the identified ceiling being deprived of sharing in the profits generated in excess, even though these may be far higher than was anticipated, thus putting him at a clear disadvantage.

As evident from the previous discussion, the accepted works of Islamic law do not mention any exception to the requirement that the profit share be an undivided proportion, which dictates, as aptly put forth by the eminent jurist Sahnûn, 'sharing in every little or much' of the profit, i.e. sharing in every unit, irrespective of the volume of total profit. The description provided by al-cAdawi of the approved nature of the profit share as 'a share of unknown quantity and known proportion' (majhûl al-kammîyyah, maclûm al-nisbah) appears in keeping with

Ibn Qudâmah, al-Mughni, Vol. 5, 148. See section on allocation of a lump sum to either partner. The answer provided by the Shari'ah Supervisory Board of Faisal Islamic Bank Sudan, in spite of mentioning this possibility, does not seem to have taken it into consideration in their final verdict. See Shari'ah Supervisory Board of Faisal Islamic Bank Sudan, Rules of the Shari'ah Supervisory Board English Series No. 5, 92, Question No. 11. 
the verdicts of all other schools. ${ }^{30}$ Therefore, it could be said that delimiting the application of the requirement that the profit share be fixed as an undivided proportion to a specific ceiling, recognising the possibility of assigning a lump sum profit not subject to proportionate division for profits exceeding it, appears unparalleled and inconsistent with the general concept of equity relationships.

The banking implications of this provision too demand consideration. Due the dominance of the interest-based financing, interest rates primarily fixed for loan capital provided by conventional banks play a major role in determining the profit that could be generated through investment of risk capital supplied by Islamic banks. Calculation of profit share by Islamic banks, even in the case of joint ventures based on equity financing, is done through employing the rate of return on capital and the period of exposure. Although the profit sharing mechanism is converted into a ratio and expressed as such on mushârakah / mudârabah agreements for Shari'ah compliance, for all intents and purposes, the underlying means adopted for calculation remain to be that of rates of return, that primarily envisage a fixed return on capital. Equity financing finds itself at sharp variance with a system based on rates of return on the issue of uncertain profits. Due to the fact that profit and loss sharing lies at the foundation of equity financing, the inherent uncertainty in this regard may not be completely eliminated. However, the predominant culture of interest based lending appears to constrain Islamic banks into adopting measures to minimise the level of uncertainty with regard to the return even in equity ventures. As a result, a large number of joint ventures currently financed by Islamic banks are ones that carry a minimum level of risk and near-certain profits. This is well-acknowledged in the query put forth by the management of the Faisal Islamic Bank of Sudan pertaining to the stipulation in question to its Shari ${ }^{6}$ ah board. ${ }^{31}$ Curbing

\footnotetext{
30 See section above on allocation of a lump sum to either partner for references.

31 In fairness to the management of Faisal Islamic Bank of Sudan, it should be stated that they had adequately outlined the background of the issue in their question. They state: “... Nowadays the chances of loss attributed to the nature or choice of the project have become very remote. Fields of investment have become so obvious that one may even claim that they have become almost automatic... Within this
} 
the uncertainty in profits in equity ventures and bringing them closer to conventional norms, thus limiting the share of proceeds entrepreneurs have to forgo for obtaining finance to interest payable on conventional loan capital, could be achieved to some extent through the stipulation in question, which could serve the purpose of inducing entrepreneurs to availing of Islamic banking facilities. However, in the process, as the profits expected are nearly certain, and the level of profits at the realisation of which the share of the bank would freeze would be fixed in a way that enables the bank to achieve the relevant rate of return and no more, the operation of the profit sharing ratio could be reduced to little more than a theoretical possibility.

Looking at the overall implications of this move, the adverse effects thereof become immediately clear. The bank's investors, the original providers of funds were already deprived of a fair return on the risk capital extended by them due to an equity financing mechanism constrained by a profit share calculation method based on rate of return cum period; now, through this measure, they would be denied even any unexpected additional amount of profit they could have gained through the fair operation of a profit sharing ratio. The possible benefit to the investors through the ventures funded by the bank generating higher profits than was expected would be effectively barred through the stipulation, which would allow the entrepreneurs lay claim to any profit realised over the specified ceiling exclusively. Thus, the maximum profit accruable to the bank's investors would be limited, as could be expected in the current scenario, to the prevalent rate of return; their funds would be freely exposed only to the prospect of earning even less profits through

recognized development in science and technology the bank, in carrying out its investment policies, enters into agreements and contracts whereby the bank mutually agrees to share the profits realized at a given percentage. Whereas the projects financed by the bank under such agreements or contracts in most instances have a high rate of return and profitability and are almost certain to make profits..." See Shari'ah Supervisory Board of Faisal Islamic Bank Sudan, Rules of the Shari'ah Supervisory Board English Series No. 5, 92, Question No. 11. The question makes it amply clear that the profits expected through the ventures are almost certain (the original Arabic version uses the term madmûnah, i.e, guaranteed), and thus reserving a lump sum would not be materially different from assigning profits based on a ratio. 
the application of the profit sharing ratio when the expected level of profits fail to materialise, and to that of capital loss. Consequently, the stipulation, by curtailing the equity mechanism from functioning even to the extent possible within the current constraints, could result in defeating a fundamental objective of equity financing, namely, achieving an equitable distribution of wealth among all segments of the populace. Thus, despite of any ancillary benefits of a short-term nature reaped by the banking industry, the stipulation appears untenable even from a perspective of maqâsid.

\section{AGREEMENT ON SUBSEQUENT AMENDMENT TO THE FIXED RATIO}

For reasons mentioned in the introduction above, Islamic banks could sometimes stipulate at the inception of equity ventures that the profit sharing ratio as agreed on the contract initially could be revised later and a new ratio adopted for sharing profits with the mutual agreement of the parties. Thus, the partners would be free to effect the profit division at the finalisation of the contract based on a ratio freshly agreed, disregarding the ratio determined at commencement. As obvious, this would require that all the partners agree on adopting the new ratio. Theoretically the need for such alteration could arise due to a partner's dissatisfaction with the original ratio agreed for profit sharing, when the progress of the venture had demanded additional labour input from one of the partners than was anticipated. For compensating the additional labour, which could be in the form of an increase of the quantity of labour or the contribution of a specialised expertise, the partners could feel the need to revise the profit sharing ratio, rather than annulling the contract. This is so because, as far as the capital contributions are concerned, these have been known at the inception, as the validity of the contract demands the existence of the capital at commencement. Any fresh infusion of capital from one of the parties or both possibly resulting in the adjustment of the capital contribution ratio could usually demand renewal of the contract. Practically, a situation where banks could contemplate alteration of the agreed ratio is when an unexpected delay in realising the proceeds gives rise to the bank not achieving the return due for the total period as dictated by the application of the rate of return. As the bank's share of the profits was initially calculated based on applying the relevant rate on 
a shorter period, the additional duration spent in recovery could be considered unproductive.

With regard to resorting to a revision of the ratio merely due to a partner not achieving an expected amount of profit as his share, it should be noted that the equity platform presumes the willingness of the parties to accept the proportionate share of any amount of proceeds generated by the venture as agreed. In an extreme situation, it could demand acceptance of even the loss of capital, proportionate to the ratio of capital input. Thus, irrespective of the amount of total profit realised, the parties are supposed to share it according to the ratio adopted. In spite of this inherent nature of equity relationships, could the parties reserve the right to revise the ratio on a later occasion, which would include the final stage of the contract where the profits realised are about to be divided, due to any of the above reasons? The Shari'ah perspective of this issue is analysed hereunder.

\section{Position of Islamic Law on the issue}

As evident, there could not be any possibility of such revision according to schools that uphold the ratio of capital input as the only ratio acceptable for profit division in contracts where every partner contributes capital. Therefore, under the Shâfici and Mâliki laws, partners in a shirkah necessarily have to carry out the division of profit and bear liability according to the capital investment ratio. Adopting any other ratio, either at the inception itself or when the venture has commenced operations is not allowed.

However, restricting profit division ratio to that of capital investment is evidently not applicable in equity contracts based on mudârabah. Therefore, we may verify whether the possibility of a later adjustment of the profit division ratio initially agreed exists under mudârabah contracts. The Shâfici school is seen to deny such a provision categorically as one that is inconsistent with the nature of a valid contract of mudârabah, similar to one of the partners being entitled to the whole profit. Any change to the profit share assigned to the fund-manager would be admissible only under a fresh contract, after the former contract is rescinded. ${ }^{32}$ Mâliki jurists appear to have allowed muḍ̂arabah 
contractors to revise the stipulated ratio and adopt a different ratio with mutual consent even after the mudârib had commenced operations. They uphold its permissibility during the tenure of the mudârabah when the capital has been converted to merchandise, as it would be tantamount to an undefined gift from one of them to the other voluntarily, which is recognised as valid in Mâliki theory. ${ }^{33}$ Such an adjustment to the ratio at this stage has been condoned because realisation of profits remains uncertain. ${ }^{34}$ However, this permission is not granted by Mâliki jurists unanimously, as some consider such adjustment valid only if effected prior to the fund manager commencing operations. This restriction is based on the fact that according to Mâliki theory, contrary to the other schools, the contract of mudârabah becomes binding (lâzim) after commencement of operations. If the partners agree on any adjustment to the profit sharing ratio before, this appears to be approved by Mâliki jurists in general, as it is similar to initiating a fresh contract. ${ }^{35}$

Hanafi jurists have upheld the possibility of adjustment to the profit sharing ratio even after mudârabah operations have resulted in profit or loss. If the partners mutually adopt a ratio different from what was agreed initially at any stage of the mudârabah, the total profit realised, i.e. what was realised before the adjustment as well as what was realised afterwards, is shared according to the ratio as agreed later, and the former ratio disregarded. ${ }^{36}$ This is because the contract is held to be in force until the capital is returned to the financier. According to Hanafi theory of binding contracts (uqûd lâzimah), during the tenure of the contract,

Shâfici position on one of the mudârabah partners being entitled to the whole profit is that the contract becomes invalid through such stipulation. If profits are realised under the contract, they belong to the financier solely. The fund manager is entitled to just recompense (ujrah al-mithl). See al-Nawawi, Rawdah al-Tâlibîn, Vol. 4, 203.

33 Al-Abdari, al-Tâj wa al-Iklîl, Vol. 5, 363.

34 This could indicate that they do not regard a change of ratio valid after the profit or loss has been ascertained.

35 Al-Khurashi, Hâshiyah al-Khurashi, Vol. 7, 156. Ibn al-Qâsim sees such an alteration acceptable even after commencement of operations. See ${ }^{\mathrm{c}} \mathrm{Abd}$ al-Salâm Sahnûn ibn Sacid, al-Mudawwanah al-Kubrâ, Vol. 12,90 .

36 Al-Sarkhasi, al-Mabsût, Vol. 22, 108, al-Shaykh Nizâm, al-Fatâwâ al${ }^{c}$ Alamkîrîyyah, Vol. 4, 322. 
any later addition to or deduction from the terms of the contract become part of the original contract, and are upheld as such. ${ }^{37}$ They assert that this principle is applicable to mudârabah, a non-binding contract $\left({ }^{c} a q d\right.$ jâ'z), a fortiori. As observed by al-Kâsâni in a similar context, it is acknowledged that the parties have the right to revoke the contract, which amounts to more than changing the terms of the contract. This is because revocation involves abolishing the essence $(a s \underline{l} l)$ of the contract as well as its characteristics (wasf), while change only involves altering the characteristics, leaving the essence intact. Therefore, the parties are necessarily entitled to changing the contract. ${ }^{38}$ The Hanafi jurist Abû Yûsuf has allowed adjustment to the profit sharing ratio in the form of an addition to or subtraction from the share of the fund manager even after distribution of profits. According to Muhammad, while reducing the fund manager's share is allowed in this instance, adding to it is not allowed. ${ }^{39}$ He reasons that the contract had concluded with the division of profits and the financier recovering his capital. The fund manager is entitled to his share against the labour he had provided, which had ceased

37 Al-Sarkhasi, al-Mabsût, Vol. 22, 108. This is when such incorporation does not necessitate invalidity of the original contract. When any later addition could result in the invalidity of the original contract, e.g. a later addition to an exchange of ribawi items, Hanafi jurists differ on whether the later addition would be incorporated to the original contract or not. See for details al-Kâsânî, Badâ 'ic al-Sanâ 'i $i^{c}$, Vol. 5, 261. Al-Kâsânî, Badâ' 'ic al-Sanâ' 'ic, Vol. 5, 259. The context relates to the right of parties in a contract of sale to add to or deduct from the price or the merchandise, and to effecting an increase in the mahr. Al-Kâsâni has drawn support for the latter from the Qur'anic verse: "there is no blame on you in what you mutually agree with subsequent to the stipulated mahr" (Q. 4: 24). This permission is subject to necessary conditions such as the consent of the other party and unity of the session. He observes that these conditions are not applicable to a decrease of the price as it is essentially a relinquishment (ibrâ') According to Imâm al-Shâfici adding to or deducting from the price or the merchandise is considered to be a gift (hibah) contracted afresh, and would not relate to the original contract of sale. This discussion carries a host of important ancillary details. Ibid.

39 Al-Sarkhasi, al-Mabsût, Vol. 22, 109, al-Shaykh Nizâm, al-Fatâwâ al'Alamkîrîyyah, Vol. 4, 322. 
with the conclusion of the contract. Therefore, its exchange (badal), i.e. the profit share, may not be increased subsequently, while it could be reduced. This is similar to a contract of sale after the sold item has ceased to exist; while the price may not be increased, it could be reduced. ${ }^{40}$

It can be gathered from the above discussion that Hanafi and Mâliki jurists are unanimous in allowing change of the profit sharing ratio before the commencement of operations. Although Hanafi jurists regard such a revision valid even after the mudârabah had resulted in profit or loss, Mâliki jurists appear to restrict the permissibility of such change to the tenure of the mudârabah, before the outcome of operations is known. Thus, it is Hanafi jurists who recognise change of the ratio prior to liquidation after the profitability of the venture has been ascertained. It could be assumed that their position in the case of shirkah would be similar, as the latter, too, happens to be a non-binding contract.

\section{Current practice}

Similar to the provision curtailing the profit share of a partner to a specific ceiling, it is evident that the provision facilitating revision of the profit sharing ratio has been a subject of interest to Islamic banks and related scholarly bodies. The issue is seen to have been analysed by a number of Shari'ah supervisory boards and conferences. Being an early entry in the arena of Islamic banking, Faisal Islamic Bank of Sudan has queried its Shari'ah supervisory board regarding the lawfulness of such a provision as recorded in the collection of the latter's rulings referred to earlier. The question relates to the permissibility of a contractual term calling for reassessment of the agreed share of profits if it is proved at the end of the operations that the percentage previously agreed was unfavourable to a party. In its answer, the Shari'ah supervisory board has upheld the

\footnotetext{
40 Al-Sarkhasi, al-Mabsût, Vol. 22, 109. This is according to the position upheld by Abû Yûsuf and Muhammad. According to Imâm Abû Ḥanifah, continued existence of the subject matter is not a requirement for any addition to or reduction of the subject matter or the price after the contract. Therefore, both increase as well as decrease is allowed. See for details al-Kâsânî, Badâ 'ic al-Sanâ ' $i^{c}$, Vol. 5, 259, 260.
} 
possibility of altering the terms governing the mudârabah contract anytime with the consent of the parties provided the newly added term is within the accepted Shari' ah rules. The bank could include a term in the mudârabah contract allowing reassessment of the profit share at the end of each operation or at the end of each year. The board has referred to the manual of Khalîl on Mâliki law in support. It has further upheld the permissibility of altering the percentage of shares in the profits in partnerships involving capital advanced by both parties. ${ }^{41}$ This position appears to have been endorsed by some other entities. The fourth Albaraka seminar held in 1984 has issued a ruling stressing that the profit shares of both the bank and the investor be fixed as undivided shares and that they remain effective during the tenure of mudârabah. If the profit ratio is to be changed in the future, the partner should be notified. The ruling holds that if the investor does not object to the change within a period stipulated for the purpose, it would be taken as an indication of his consent. ${ }^{42}$

Shari'a Standards 2002 of AAOIFI has referred to the above rulings by the Albaraka seminar and the Shari'ah board of Faisal Islamic Bank of Sudan in support of its recognition of the permissibility of an agreement to change the ratio of profit distribution anytime in a contract of mudârabah. The basis for this is that profit is a right belonging to the parties and the provision in question does not lead to a prohibited act such as preclusion of sharing in profit; rather, it makes the parties partners in profit. ${ }^{43}$ In the case of mushârakah, after upholding the impermissibility of deferring the determination of profit percentages due to each partner until the realisation of profit, the Shari 'ah Standards holds that the parties may bilaterally agree to amend the percentages of profit sharing on the date of distribution, on the basis that the profit belongs to them. ${ }^{44}$

$41 \quad$ Shari'ah Supervisory Board of Faisal Islamic Bank Sudan, Rules of the Shari'ah Supervisory Board English Series No. 5, 87, Question No. 4. The question and the answer are partially reproduced in the Compendium, 212.

42 Dallah Albaraka, Fatawa: Shariah Rulings on Economics, 99, Compendium, 216.

43 AAOIFI, Sharia Standards 2002, standard No. 8/3, 233, 243, and Sharia Standards 2010, 237, 247.

44 Sharia Standards 2002, mushârakah standard No. 3/1/5/2, 204, 221, and Sharia Standards 2010, 207, 224. 


\section{Analysis}

In essence, the above rulings have as their base the permissibility to amend the profit sharing ratio in mudârabah contracts as upheld by the Hanafi and Mâliki schools in varying degrees. The unlimited permissibility recognised by the modern bodies allowing the partners to alter the ratio at anytime is restricted by Mâliki jurists to the period before the calculation of profit and loss. However, as shown above, Hanafi jurists have upheld its validity even at the point of liquidation. The ruling could be extended to shirkah contracts based on the reasons provided by Hanafi jurists. Thus, the rulings appear to be in accordance with the theory of equity contracts as expounded by the Hanafi school. It is noteworthy here that what is recognised by Hanafi jurists is a spontaneous change of the profit ratio at a later stage based on mutual consent. A stipulation in the original contract that envisages the prospect of such a change in the future could not possibly be ascribed to Hanafi jurists, and should be regarded as an original ruling by the contemporary bodies.

It would be pertinent to survey the implications of this provision in a banking perspective. The observations made earlier with regard to the provision to curtail the operation of the profit ratio to a specific ceiling could also be applicable here to a large extent. ${ }^{45}$ As pointed out there, the indefinite nature of the profit share in Islamic equity financing modes is a vital aspect where modern banking practice finds itself at variance. The provision to revise the profit sharing ratio could easily be adopted as a tool of convenience to circumvent the Shari'ah regulation in this regard, i.e. that the profit share be fixed as an undivided portion. In a business environment where interest based lending is the norm and the provisions of which are considered to be conducive, parties to an equity contract may perceive it to be in their interest to adopt measures that reduce the uncertainty in the amount of profit accruing to either of them, or facilitate one of them to achieve a predetermined rate of return on his capital. The equity structure as upheld by Islamic Shari'ah emphasises determination of the profit sharing ratio clearly at the outset, and does

$45 \quad$ See section above on contemporary Shari'ah approach to stipulation on profit exceeding a specific amount. 
not allow its deferment until realisation of profits. Deciding the ratio of profit division may not be vested on boards of management or other relevant bodies to be carried out at the end of the term after verification of profitability. ${ }^{46}$ However, this end could be conveniently achieved by incorporating the above provision in the contract.

On the other hand, it should also be remembered that the permissibility of such alteration presumes a contract made by partners enjoying equal bargaining positions, able to assert their individual demands freely. However, standard agreements of mudârabah and mushârakah proffered by Islamic banks generally belong to contracts of adhesion, where the client / partner is not given much leeway for insisting on his terms. Therefore, after finalising an agreement that contains the above clause, the client could not be expected but to agree to any ratio as unilaterally decided by the bank management after realisation of profits. As provided in the ruling by the Albaraka seminar mentioned above, even lack of response from the client could be held to indicate acceptance. Thus, the inherent danger of the provision in question being misused should not be underestimated. If the provision is adopted for securing ends incompatible with the philosophy of equity financing, it could prove detrimental to the cause of Islamic banking in general.

Therefore, it is necessary that incorporation of provisions of this nature should not be allowed or encouraged with regard to every Islamic bank without distinction. Rather, before approving the inclusion of such clauses in mud̂arabah / mushârakah agreements, Shari'ah supervisory boards concerned should study the nature and disposition of their respective banks individually, choosing their incorporation only where the possibility of misuse is minimum.

\section{CONCLUSION}

Equity participation, being a mode based on joint investment for mutual sharing of gains and liability, is adopted without the encumbrance of

46 This is the verdict of $2^{\text {nd }}$ Islamic banking conference held in Kuwait, 1983, and the first meeting of the board for fatwâ and Shari'ah supervision of Islamic banks held in Cairo, 1983. See Dubai Islamic Bank, al-Fatâwa al-Shari' îyyah fí al-A'mâl al-Maṣrafìyyah, Vol. 1, 32, 39. 
ensuring a preset capital return to a single partner by individuals and business firms in all societies. Islamic banks need to adopt an approach similar to these and strive at desisting from furthering their identity as lending institutions, a pioneer step towards which goal would be upholding a proper profit and loss sharing mechanism. For realising the benefits of equity financing, its operation should not be hindered through measures that strip it of its characteristics. A central pillar of the equity structure is the unbridled operation of the profit sharing ratio. Restriction of its application to a stipulated level of profits, thereby enabling a partner to claim unlimited profits while the profit share of the other is restricted to a maximum ceiling cannot be regarded to be consistent with the theory of equity participation. Any measure that curtails the free operation the profit sharing mechanism could result in defeating the objectives of equity financing. Similarly, a provision that envisages the possibility of adjusting the profit sharing ratio prior to liquidation does not seem appropriate in the prevalent environment of interest based banking, and could be easily misused. While these measures could realise some temporary benefit to Islamic banks, they may become deep-rooted in the concept of equity financing itself, thus making it operate subservient to debt financing norms forever. Therefore, introduction of such measures should be carefully monitored by the sharî ${ }^{\mathrm{c}}$ ah supervisory boards of Islamic banks and other relevant bodies so as to avoid their harmful effects. 